\title{
Utilization of Social Media Marketing By Young Business Players in Binjai City in Developing Customer Equity
}

\author{
T. Enita Rosmika ${ }^{1}$, Amrin Mulia Utam² \\ ${ }^{1}$ Universitas Amir Hamzah, Medan, Indonesia \\ ${ }^{2}$ Universitas Medan Area, Medan, Indonesia \\ shalihahilna@gmail.com
}

\begin{abstract}
Various lines of business and marketing in all dimensions of the world have been digitized, the use of social media by business actors has had a major influence in introducing their products more effectively and efficiently, the role of social media in increasing sales and building communities is more targeted than conventional media use. This research study aims to analyze the use of social media by young entrepreneurs in the variable consumption, curation, creation and collaboration with customer equity in young entrepreneurs in Binjai City. The methods used were questionnaires and interviews as well as direct field surveys. The results obtained state that social media Instagram or Facebook is preferred compared to others as a means of promotion for business people, women entrepreneurs prefer Instagram. From male entrepreneurs. The results also show that the use of social media in marketing has a positive and significant effect on customer equity in young entrepreneurs in Binjai City.
\end{abstract}

Keywords

consumption; curation; creation; collaboration; customer equity, social media

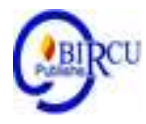

\section{Introduction}

Almost all internet users also use Social Media as an alternative means of digital communication to those around them. This can be seen from the development of social media. Social Media was started by Friendster in 2002 which was discovered by Jonathan Abram, in 2004 Facebook was discovered by Mark Zuckerberg and two years later in 2006 Twitter was discovered by Jack Dorsey and most recently in 2010 Social Media Instagram and Path in 2011.

Social media in the real world is connecting with people or colleagues, friends, and using that media to meet new people (Khairifa et al, 2019). Indonesia is one of the countries whose Social Media growth is very fast and Social Media has now become a trend to spread an issue, knowledge or information quickly to internet users. According to Social Media is a group of internet-based applications built on the ideological and technological framework of Web 2.0. Currently, one of the Social Media that is very widely used in Indonesia is Facebook. The growth of its users in Indonesia itself is quite significant. A survey conducted by We Are Social Singapore shows that, as of November 2015, active social media users in Indonesia have reached 79 million people. This number has grown by 19 percent since January 2014. The social media that are frequently accessed are Facebook, Twitter, Google+, Instagram, Skype, Pinterest and Line. On average, Indonesians spend 2 to 3 hours per day accessing social media. Companies should pay attention to the use of Social Media as another way to market a product and change the habiTS that previously used conventional marketing through brochures, advertising on TV to digital marketing through the internet or it can be called internet marketing. 
Globalization and free markeTS are challenges for Small and Medium Enterprises (SMEs) to continue to survive. The ASEAN Economic Community or AEC, which is a free trade system or free trade between ASEAN member countries, is a challenge for Small and Medium Enterprises (SMEs) to continue to survive in free market competition. The easy dissemination of information and the freer competition has increased consumer awareness of the large selection of goods and services to choose from. If SMEs do not fix their marketing strategies to increase sales, they will be threatened with bankruptcy. For this reason, SMEs need to see various potential alternative media to be used as marketing media.

One of the potentials that can be exploited is information technology. The development of information technology nowadays makes people no longer have to question the boundaries of distance, space and time. Information technology gave birth to the internet, the internet offers many benefits for MSMEs to increase the marketing of their products. In addition, the internet also provides benefits to increase the opportunities for MSMEs to collaborate with other entrepreneurs. One of the internet technologies that is growing rapidly and has the potential to encourage the marketing of MSMEs is social media. Social media has the potential of connecting people easily and for free. Social media was chosen because the growth of its users around the world is increasing every year.

Marketing communication can shape brand equity and improve promotional performance (Bogan in Amin \& Priansah, 2014). Marketing communication using social media helps brands and consumers communicate both ways directly with each other regardless of time, place, and medium. In addition, the brand has gained exposure and a stronger relationship with consumers (Kim \& Ko, 2012).

In recent years, Binjai City's Small and Medium Micro Small and Medium Enterprises have continued to develop as more and more people are pursuing these homebased businesses as their main or secondary livelihood. The high rate of growth of MSMEs is considered of course also inseparable from the increasingly incessant efforts of the government to encourage people to become entrepreneurs who are also able to open new jobs. So that the high unemployment rate, which is currently increasingly alarming, especially among the productive age groups, can be further suppressed. In 2009 there were around 22 thousand MSME players in Binjai City and that number continued to increase until 2015 the number reached around 300 thousand. The high growth of MSMEs is certainly very encouraging because it can also reduce unemployment at the same time.

According to Kim \& Ko (2012), marketing activities through Social Media carried out by a brand have a positive influence on customer equity. Marketing that has been carried out can affect customer equity due to the three driving factors of customer equity, namely value equity, relationship equity, and brand equity, which are also influenced by the social media activities undertaken. Social Media Marketing (SMM) is two-way communication to attract empathy for younger users and can even evoke the same emotions in older groups of users. According to Hasbullah et al (2018), Communication is the process of delivering messages by someone to other people to tell, change attitudes, opinions or behavior either directly orally or indirectly through the media. 


\section{Review of Literature}

\subsection{Customer Equity}

Consumer equity is defined as a long-term asset with consumers that is based on a well-established and long-established relationship. (Kim and Ko, 2012). Customer equity is one method of connecting the marketing program and the likelihood that a customer will benefit the company in the future. The customer equity approach is inseparable from the basic concept of the marketing mix which includes product, price, place, promotion, people, process and physical evidence.

Rust, Lemon and Zeithaml (2000) state that consumer equity can be the most important component for producers. Consumers remain for producers is an important asset for the future of producers. This shows how consumer equity can determine the various decisions taken by producers.Rust, Zeithaml and Lemon (2001) distinguish three factors (drivers) that affect customer equity, namely value, brand and relational equity.

\subsection{Social Media Marketing}

According to Richter and Koch (2007) in Situmorang (2016), Social Media is an online application, means and media aimed at facilitating interaction, collaboration and sharing of material. According to Kotler (2012) and Social media is a means for consumers to share text, images, audio and video information with each other and with the company and vice versa. Social media according to Kotler (2012) is divided into three types, namely: 1.Online Communities and Forums. 2.Blog-gers. And 3Social Networks.

According to Kaplan and Hanlein (2010), social media marketing is a technique that uses social media as a means to promote a product (Link to the Online Business Website page) or a specific service or product. Consumer patterns in using social media can be seen through $4 \mathrm{C}$, namely consumption, curation, creation, and collaboration (Evans and Mckee, 2010).

The following are the stages in the engagement process, from starting a conversation with consumers to getting consumers to generate positive feedback for the company:

1. Consumption

Consumption in the context of social media, it is the process of retrieving, reading, viewing, or listening to the content of the company website. Consumption is the first step in starting other online activities.

2. Curation

Curation is the act of sorting, determining and viewing or in other words describing the content of the company website.

3. Creation

Creation is the next stage after curation, where this creation is a step that determines the number of responses to an event.

4. Collaboration

Collaborationis the result of consumption, curation and creation which gives rise to a large individual activity.

The hypothesis of this study are:

Social media Marketing which consists of Consumption, Curation, Creation and Collaboration, which have a positive and significant effect partially or simultaneously on Customer equity in Young Entrepreneurs in Binjai City. 


\section{Research Methods}

The type of research in this research is associative research, which is research that connecTS two or more variables (Situmorang, 2020). The variables associated in this study are social media marketing which consists of Consumption, Curation, Creation and Collaboration towards customer equity. The research was conducted among young entrepreneurs who actively market their producTS using social media in Binjai City. This research was conducted from May 2020 to June 2020. The population in this study were young entrepreneurs in Binjai City who market their products through an unknown number of social media. Because the number of young entrepreneurs who market their producTS on social media is not known, the supramono formula is used to determine the sample. Because the $\mathrm{p}$ value is not known from research or other literature, a maximal estimation can be carried out with $\mathrm{p}=0.5$ and the specified error rate $(\mathrm{d})$ is $10 \%$. And the number of samples of this study were 96 respondents.

The sampling technique uses non-probability sampling, The type of non-probability sampling used is purposive sampling, namely the sampling technique with certain considerations. The criteria in this study are:

1. Young Entrepreneurs who run their business through Social Media

2. Age of Entrepreneurs under 40 years

3. Minimum length of business is 3 months

\section{Data Analysis Technique}

The data analysis technique used to test the hypothesis in this study is Multiple Linear Regression Analysis. The Classical Assumption Test is carried out by performing the Normality Test, Heteroscedasticity Test and Multicollinearity Test Hypothesis Test with Concurrent Test (F Test) F statistical testing is an overall regression test that shows whether the independent variable as a whole has an influence on the dependent variable. And the Partial Signification Test (t-test) was conducted to determine whether independent variables such as social media marketing which consisted of consumption (X1), curation (X2), creation (X3) and collaboration (X4) partially had a significant effect on the dependent variable. Namely Customer equity. This research was conducted with a significance level of $5 \%$ or 0.5 .

\section{Result and Discussion}

\subsection{Variable Descriptive Analysis}

RespondenTS in this study were Young Entrepreneurs in Binjai City who market their producTS using social media. There are 17 poinTS of statement; 4 items of Consumption variable statement (X1), 3 items of Curation variable statement (X2), 3 items of Creation variable statement (X3), 3 items of Collaboration statement and 4 items of Customer Equity (Y) variable statement. The questionnaire was distributed to 100 respondenTS. The following is the distribution of respondents' answers. 


\section{a. Distribution of Respondents' Answers to the Consumption Variables}

Table 1. Distribution of Respondents' Answers to Consumption Variables

\begin{tabular}{|c|c|c|c|c|c|c|c|c|c|c|c|}
\hline \multirow{2}{*}{ Item No. } & \multicolumn{2}{|c|}{ STB } & \multicolumn{2}{|c|}{ TB } & \multicolumn{2}{|c|}{ KB } & \multicolumn{2}{|c|}{ B } & \multicolumn{2}{|c|}{ SB } & \multirow{2}{*}{ Average score } \\
\cline { 2 - 11 } & $\mathrm{F}$ & $\%$ & $\mathrm{~F}$ & $\%$ & $\mathrm{~F}$ & $\%$ & $\mathrm{~F}$ & $\%$ & $\mathrm{~F}$ & $\%$ & 4.20 \\
\hline 1 & 0 & 0 & 0 & 0 & 18 & 18 & 28 & 28 & 54 & 54 & 4.56 \\
\hline 2 & 0 & 0 & 1 & 1 & 12 & 12 & 43 & 43 & 50 & 50 & 4.25 \\
\hline 3 & 0 & 0 & 0 & 0 & 8 & 8 & 46 & 46 & 43 & 43 & 4.58 \\
\hline 4 & 0 & 0 & 1 & 1 & 11 & 11 & 43 & 43 & 51 & 51 & \\
\hline
\end{tabular}

Source: Research Results, 2020 (processed data)

Consumption in the context of social media, it is the process of retrieving, reading, viewing, or listening to the content of the company website. Consumption is the first step in starting other online activities.

\section{b. Distribution of Respondents' Answers to the Curation Variable}

Table 2. Distribution of Respondents' Answers to the Curation Variable

\begin{tabular}{|c|c|c|c|c|c|c|c|c|c|c|c|}
\hline \multirow{2}{*}{ Item No. } & \multicolumn{2}{|c|}{ STB } & \multicolumn{2}{|c|}{ TB } & \multicolumn{2}{|c|}{ KB } & \multicolumn{3}{|c|}{ B } & \multicolumn{3}{|c|}{ SB } & Average \\
\cline { 2 - 12 } & $\mathrm{F}$ & $\%$ & $\mathrm{~F}$ & $\%$ & $\mathrm{~F}$ & $\%$ & $\mathrm{~F}$ & $\%$ & $\mathrm{~F}$ & $\%$ & score \\
\hline 1 & 4 & 4 & 11 & 11 & 26 & 26 & 36 & 36 & 18 & 18 & 3.43 \\
\hline 2 & 10 & 10 & 7 & 7 & 18 & 18 & 45 & 45 & 25 & 25 & 3.78 \\
\hline 3 & 9 & 9 & 13 & 13 & 28 & 28 & 41 & 41 & 14 & 14 & 3.48 \\
\hline
\end{tabular}

Source: Research Results, 2020 (processed data)

Curation is the act of sorting, determining and viewing or in other words describing the content of the company website. Curation can make site content more useful to others.

\section{c. Distribution of Respondents' Answers to the Creation Variable}

The resulTS of the determinant validity of the test data in this research are shown in the following table:

Tabel 3. Distribution of Respondents' Answers to the Creation Variable

\begin{tabular}{|c|c|c|c|c|c|c|c|c|c|c|c|}
\hline \multirow{2}{*}{ Item No. } & \multicolumn{2}{|c|}{ STB } & \multicolumn{2}{|c|}{ TB } & \multicolumn{2}{|c|}{ KB } & \multicolumn{3}{|c|}{ B } & \multicolumn{3}{|c|}{ SB } & \multirow{2}{*}{$\begin{array}{c}\text { Average } \\
\text { score }\end{array}$} \\
\cline { 2 - 13 } & $\mathrm{F}$ & $\%$ & $\mathrm{~F}$ & $\%$ & $\mathrm{~F}$ & $\%$ & $\mathrm{~F}$ & $\%$ & $\mathrm{~F}$ & $\%$ & \\
\hline 1 & 8 & 8 & 11 & 11 & 18 & 18 & 43 & 43 & 25 & 25 & 3.76 \\
\hline 2 & 9 & 9 & 15 & 15 & 28 & 28 & 32 & 32 & 26 & 26 & 3.71 \\
\hline 3 & 4 & 4 & 14 & 14 & 20 & 20 & 39 & 39 & 29 & 29 & 3.76 \\
\hline
\end{tabular}

Source: Research Results, 2020 (processed data)

Creation is the next stage after curation, where this creation is a step that determines the number of responses to an event. 


\section{d. Distribution of Respondents' Answers to Collaboration}

Table 4. Distribution of RespondenTS' Answers to Collaboration Variables

\begin{tabular}{|c|c|c|c|c|c|c|c|c|c|c|c|}
\hline \multirow{2}{*}{ Item No. } & \multicolumn{2}{|c|}{ STB } & \multicolumn{2}{|c|}{ TB } & \multicolumn{2}{|c|}{ KB } & \multicolumn{2}{|c|}{ B } & \multicolumn{2}{|c|}{ SB } & \multirow{2}{*}{$\begin{array}{l}\text { Average } \\
\text { score }\end{array}$} \\
\cline { 2 - 13 } & $\mathrm{F}$ & $\%$ & $\mathrm{~F}$ & $\%$ & $\mathrm{~F}$ & $\%$ & $\mathrm{~F}$ & $\%$ & $\mathrm{~F}$ & $\%$ & 3.58 \\
\hline 1 & 9 & 9 & 14 & 14 & 25 & 25 & 33 & 33 & 24 & 24 & 3.63 \\
\hline 2 & 5 & 5 & 14 & 14 & 18 & 18 & 44 & 44 & 21 & 21 & 3.71 \\
\hline 3 & 10 & 10 & 16 & 16 & 24 & 24 & 28 & 28 & 24 & 24 & \multirow{2}{*}{} \\
\hline
\end{tabular}

Source: Research Results, 2020 (processed data)

Collaboration is the result of consumption, curation and creation which gives rise to a large individual activity.

\section{e. Distribution of Respondens' Answers to Customer Equity}

Table 5. Distribution of Respondents' Answers to Customer Equity Variables

\begin{tabular}{|c|c|c|c|c|c|c|c|c|c|c|c|}
\hline \multirow{2}{*}{$\begin{array}{c}\text { Item } \\
\text { No. }\end{array}$} & \multicolumn{2}{|c|}{ STB (1) } & \multicolumn{2}{|c|}{ TB (2) } & \multicolumn{2}{c|}{ KB (3) } & \multicolumn{2}{c|}{ B (4) } & \multicolumn{2}{c|}{ SB (5) } & Average \\
\cline { 2 - 11 } & $\mathrm{F}$ & $\%$ & $\mathrm{~F}$ & $\%$ & $\mathrm{~F}$ & $\%$ & $\mathrm{~F}$ & $\%$ & $\mathrm{~F}$ & $\%$ & score \\
\hline 14 & 4 & $4 \%$ & 2 & 2 & 8 & $8 \%$ & 44 & $44 \%$ & 39 & $39 \%$ & 4.04 \\
\hline 15 & 7 & $7 \%$ & 19 & $19 \%$ & 22 & $22 \%$ & 36 & $36 \%$ & 18 & $18 \%$ & 3.39 \\
\hline 16 & 2 & $2 \%$ & 19 & $19 \%$ & 33 & $33 \%$ & 40 & $40 \%$ & 9 & $9 \%$ & 3.35 \\
\hline 17 & 5 & $5 \%$ & 17 & $17 \%$ & 21 & $21 \%$ & 33 & $33 \%$ & 25 & $25 \%$ & 5.57 \\
\hline
\end{tabular}

Source: Research Results, 2020 (processed data)

Customer Equity be one of the methods to connect the marketing program and the likelihood that a customer will benefit the company in the future.

\subsection{Classic Assumption Test}

The results of the normality test can be seen in the following graphic:

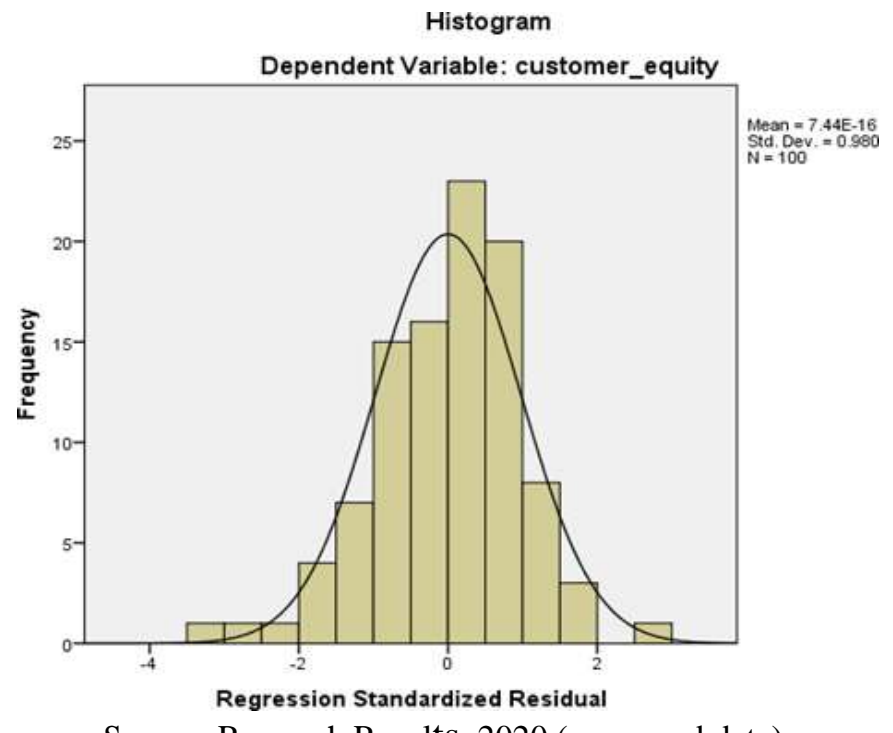

Source: Research Results, 2020 (processed data)

Figure 1. Histogram

Here are the results of the Normal P - Plot of Regresson Standardized Residual: 


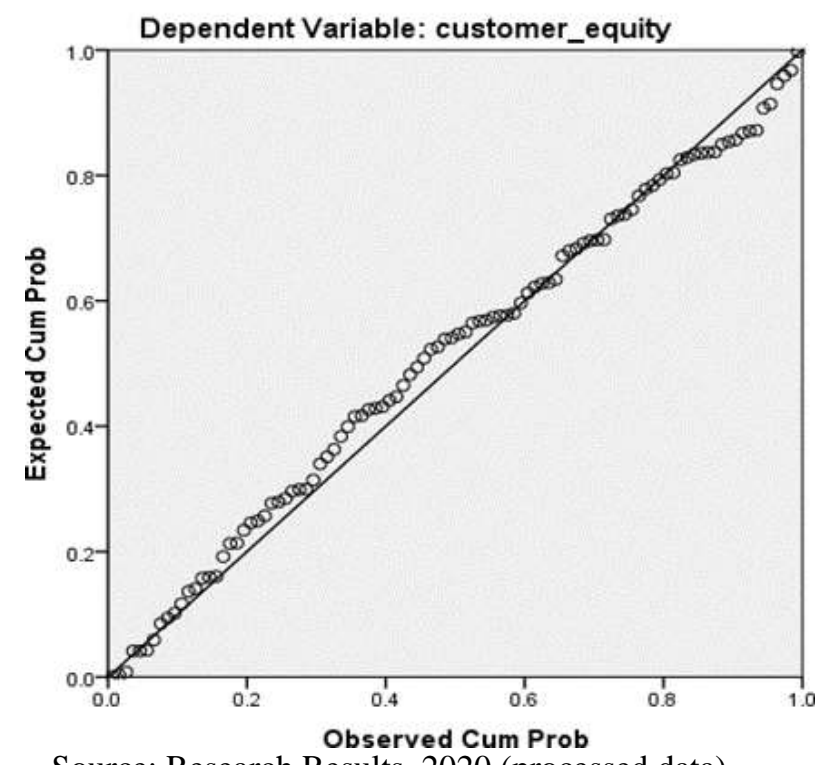

Source: Research Results, 2020 (processed data)

Figure 2. Normal P - Plot of Standardized Residual Regression

Table 6. The Kolmogorov-Smirnov test

\begin{tabular}{|c|c|c|}
\hline & & $\begin{array}{l}\text { Unstandardized } \\
\text { Residual }\end{array}$ \\
\hline $\begin{array}{l}\mathrm{N} \\
\text { Normal Parameters }{ }^{\mathrm{a}, \mathrm{b}}\end{array}$ & $\begin{array}{l}\text { Mean } \\
\text { Std. } \\
\text { on }\end{array}$ & $\begin{array}{r}100 \\
.0000000 \\
2.34416654\end{array}$ \\
\hline $\begin{array}{l}\text { Most Extreme Differences } \\
\text { Test Statistic } \\
\text { Asymp. Sig. (2-tailed) }\end{array}$ & $\begin{array}{l}\text { Absolute } \\
\text { Positive } \\
\text { Negative }\end{array}$ & $\begin{array}{r}.064 \\
.063 \\
-.064 \\
.064 \\
.200^{\mathrm{c}, \mathrm{d}}\end{array}$ \\
\hline
\end{tabular}
a. Test distribution is Normal.
b. Calculated from data.
c. Lilliefors Significance Correction.
$\mathrm{d}$. This is a lower bound of the true significance.

Source: Research Results, 2020 (processed data)

Based on Table 6, it is known that the Asymp. Sig. (2-tailed) is 0.200 and above a significant value (0.05), in other words, the residual variables are normally distributed.

The statistical approach is done by using the Glejser test. The following are the results of the processing: 
Table 7. Glejser Test

\begin{tabular}{|c|c|c|c|c|c|}
\hline \multirow[b]{2}{*}{ Model } & \multicolumn{2}{|c|}{ Unstandardized Coefficients } & \multirow{2}{*}{$\frac{\text { Standardized Coefficients }}{\text { Beta }}$} & \multirow[b]{2}{*}{$\mathrm{T}$} & \multirow[b]{2}{*}{ Sig. } \\
\hline & $\mathrm{B}$ & Std. Error & & & \\
\hline $1 \quad$ (Constant) & & & & & \\
\hline & 2.609 & 1.192 & & 2.192 & .032 \\
\hline Consumption & .032 & .066 & .051 & .484 & .631 \\
\hline Curation & -.091 & .066 & -.182 & -1.372 & .172 \\
\hline Creation & -.026 & .066 & -.057 & -.407 & .683 \\
\hline Collaboration & -.007 & .063 & -.014 & -.117 & .905 \\
\hline
\end{tabular}

Source: Research Results, 2020 (processed data)

Table 8. Multicollinearity Test Results

\begin{tabular}{|l|c|c|}
\hline \multirow{2}{*}{\multicolumn{1}{|c|}{ Variabel }} & \multicolumn{2}{|c|}{ Collinierity Statistics } \\
\cline { 2 - 3 } Consumption & Tolerance & VIF \\
\hline Curation & .947 & 1.059 \\
\hline Creation & .563 & 1.783 \\
\hline Collaboration & .497 & 2.023 \\
\hline
\end{tabular}

a. Dependent Variable: Customer. Equity

Source: Research Results, 2020 (processed data)

Based on Table 8, all VIF values are smaller than 5 and their tolerance, is greater than 0.1 , therefore, it can be concluded that there ,is no multicollinearity problem in this study.

\subsection{Multiple Linear Regression Analysis}

Multiple regression analysis was used to determine the effect of the independent variables (Consumption, Curation, Creation, Collaboration) on the dependent variable (Customer Equity) which was carried out respondents of Young Entrepreneurs in Binjai City who market their products using social media.

Table 9. Multiple Linear Regression

Coefficients

\begin{tabular}{|l|r|r|r|r|r|}
\hline \multirow{2}{*}{ Model } & \multicolumn{2}{|c|}{ Unstandardized Coefficients } & Standardized Coefficients & & \\
\cline { 2 - 6 } & \multicolumn{1}{|c|}{$\mathrm{B}$} & Std. Error & Beta & $\mathrm{T}$ & Sig. \\
\hline 1 (Constant) & 3.144 & 1.917 & & 1.642 & .104 \\
Consumption & .223 & .104 & .173 & 2.124 & .036 \\
Curation & .229 & .109 & .224 & 2.112 & .038 \\
Creation & .237 & .108 & .245 & 2.173 & .032 \\
Collaboration & .216 & .104 & .216 & 2.112 & .037 \\
\hline
\end{tabular}

a. Dependent Variable: customer_equity

Source: Research Results, 2020 (processed data)

Hypothesis testing can be seen from Table 10 which shows that the value of Fcount (16.440)> Ftable (2.70). This shows that the independent variables consisting of the Consumption, Curation, Creation, Collaboration variables simultaneously have a significant effect on the Customer Equity variable. 
Table 10. F Test Results ANOVA $^{\mathrm{a}}$

\begin{tabular}{|c|c|c|c|c|c|}
\hline Model & Sum of Squares & Df & Mean Square & $\mathrm{F}$ & Sig. \\
\hline Regression & 377.573 & 4 & 94.142 & 16.44 & $.000^{\mathrm{b}}$ \\
\hline Residual & 545.017 & 94 & 5.727 & & \\
\hline Total & 920.591 & 98 & & & \\
\hline
\end{tabular}

a. Dependent Variable: customer_equity

b. Predictors: (Constant), collaboration, consumption, curation, creation

Source: Research Results, 2020 (processed data)

The partial results of hypothesis testing can be seen in Table 11 as follows:

Table 11. Hypothesis Test Results Partially ( $t$ test)

Coefficients $^{\mathrm{a}}$

\begin{tabular}{|c|c|c|c|c|c|c|}
\hline \multirow[b]{2}{*}{ Model } & \multicolumn{2}{|c|}{$\begin{array}{l}\text { Unstandardized } \\
\text { CoefficienTS }\end{array}$} & \multirow{2}{*}{\multicolumn{2}{|c|}{$\begin{array}{r}\begin{array}{r}\text { Standardized } \\
\text { CoefficienTS }\end{array} \\
\text { Beta }\end{array}$}} & \multirow[b]{2}{*}{$\mathrm{T}$} & \multirow[b]{2}{*}{ Sig. } \\
\hline & $\mathrm{B}$ & Std. Error & & & & \\
\hline 1 (Constant) & 3.144 & 1.917 & & & 1.642 & .104 \\
\hline consumption & .222 & .105 & & .173 & 2.125 & .037 \\
\hline Curation & .228 & .109 & & .223 & 2.113 & .038 \\
\hline Creation & .236 & .107 & & .245 & 2.174 & .033 \\
\hline collaboration & .217 & .103 & & .217 & 2.110 & .038 \\
\hline
\end{tabular}

a. Dependent Variable: customer_equity

Source: Research Results, 2020 (processed data)

Table 12. Testing the Coefficient of Determination $\left(\mathrm{R}^{2}\right)$

Model Summary ${ }^{b}$

\begin{tabular}{|l|r|r|l|l|l|}
\hline Model & $\mathrm{R}$ & R Square & $\begin{array}{l}\text { Adjusted R } \\
\text { Square }\end{array}$ & $\begin{array}{l}\text { Std. Error of the } \\
\text { Estimate }\end{array}$ & $\begin{array}{l}\text { Durbin- } \\
\text { WaTSon }\end{array}$ \\
\hline 1 & $.640^{\mathrm{a}}$ & .408 & .383 & 2.39303 & 2.125 \\
\hline
\end{tabular}

a. Predictors: (Constant), collaboration, consumption, curation, creation

Dependent Variable: customer_equity

Source: Research Results, 2020 (processed data)

\subsection{Discussion}

All SMEs (UKM) that are used as objects in this study have implemented social media as a medium for corporate information and communication. Most SMEs (UKM) use various types of social media to market and advertise company merchandise and services. Almost all SMEs(UKM) use social media . Instagram, Facebook and to display company profiles and company product galleries. Most companies use Line, Whats App, and e-mail for corporate information/communication media and marketing of company products.

In addition, some SMEs (UKM) also use Blog, Line, Path and Youtube to display company profiles and as media for company information. Nearly half of the SMEs (UKM) observed allocated an operational cost budget of Rp. 500,000 - Rp. 1,000,000 to manage social media as a medium for information/communication and company marketing. And most SMEs (UKM) update information on social media every day. 
The results of research conducted by researchers show that social media Instagram, Facebook and Bbm tend to be preferred because of their ease of sharing information and attracting attention from target markets. Instagram, with the ease of posting visual displays in the form of still images and short videos, will make the products that are uploaded most often have a higher tendency to attract the attention of consumers. Facebook with the like function and the ease of sharing features for sharing information among Facebook users has a viral effect that can improve product marketing performance, coupled with the ease of interacting with previous comments which gives a domino effect to strengthen product image.

Other types of social media that have the potential and can also be used as corporate marketing communications but have not been used by the object of this research include Line, Whatsapp, Google+, LinkedIn, Pinterest, Tumblr, MySpace. From the description previously explained that based on the results of multiple linear regression analysis, it is known that simultaneously Social Media marketing of Consumption, Curation, Creation and Collaboration has a positive and significant effect on Customer Equity. The resultsS of this study are also in line with previous research conducted by Arief and Millanyani (2015) that social media marketing which consiSTS of context, communication, collaboration and connection has a positive and significant effect on purchase intention, which distinguishes previous research where Arief and Millinyani measured social. Media marketing with context, communication, collaboration and connection. Likewise with Marta and William's research (2016) which states that social media through Instagram posts has a positive and significant effect on customer brand equity, previous research is in line with this research because it proves that Instagram has an influence in increasing brand equity, previous research also states that if the more subscribers who upload photos via their Instagram account, the posting of these photos will be able to increase their brand equity (Customer Equity).

\section{Conclusion}

The results of this study aim to determine and analyze the extent of the influence of social media marketing consisting of Consumption, Curation, Creation and Collaboration on customer equity in young entrepreneurs in Binjai City.

In this study the conclusions are as follows:

1. Simultaneously, Consumption, Curation, Creation and Collaboration have a positive and significant effect on customer equity in young entrepreneurs in Binjai City.

2. Partially, Consumption, Curation, Creation and Collaboration have a positive and significant effect on customer equity in young entrepreneurs in Binjai City.

\section{References}

Abadi, H. R., Kabiry, N., \& Forghani, M. H. (2013). Analyzing the effect of customer equity on satisfaction. International journal of academic research in business an social science

Amin, M. A. S., Priansah, P. (2019). Marketing Communication Strategy To Improve Tourism Potential. Budapest International Research and Critics Institute-Journal (BIRCI-Journal), 160-166.Arief, G. M. (2015). Pengaruh Social Media Marketing Melalui Instagram Terhadap Minat Beli Konsumen Sugar Tribe. Jurnal Administrasi Bisnis . 
Evans, D., \& Mckee, J. (2010). Social Media Marketing: The Next Generation of Business Engagement. Indiana: Wiley Publishing Inc.

Faiza, H., \& Daryanti, S. (2013). Analisis pengaruh aktivitas Social Media Marketing terhadap Customer Equity pada Merek New Luxury (studi kasus merek Zara). Jurnal Universitas Indonesia .

Ghozali, I. (2013). Aplikasi Analisis dengan Program SPSS. Semarang: Penerbit Universitas Diponegoro.

Gujarati, D. (2003). Ekonometrika Dasar Terjemahan : Sumarno Zain. Jakarta: Penerbit Erlangga.

Gurnelius, S. (2011). 30-Minute Social Media Marketing. United States: McGraw-Hill Companies.

Hasbullah, et al. (2018). Communication Pattern of Wilayatul Hisbah, Lhokseumawe City in Implementing Amar Makruf Nahi Mungkar. Budapest International Research and Critics Institute-Journal (BIRCI-Journal), 194-205.

Kaplan, A. M., \& Haenlein, M. (2012). Social Media: Back to the roots and backs to the future. Journal of system and information technology, 101-104.

Khairifa, F., et al. (2019). The Relationship of Social Media Usage to the Satisfaction and Practice of Friendship (Silaturahmi) among Students of Universitas Sumatera Utara. Budapest International Research and Critics Institute-Journal (BIRCI-Journal), 575589.

Kim, A. J., \& Ko, E. (2012). Do Social Media Marketing enhance Customer Equity? An empirical study of luxury fashion brand. Journal of Business Research, 1480-1486.

Kim, J., Kim, J., \& Johnson, K. (2010). The customer-salesperson relationship and sales effectiveness in luxury fashion stores: the role of self monitoring. J Glob Fashion Mark , 230-9.

Mangold, W. G., \& Faulds, D. J. (2009). Social Media : the new hybrid element of the promotion mix. Busines Horizons, 357-365.

Priambada, S. (2015). Manfaat penggunaan Media Sosial pada Usaha Kecil Menengah. Jurnal Seminar Nasional Sistem Informasi Indonesia.

Prihandini, F. (2014). Analisis pengaruh media sosial terhadap ekuitas konsumen produk sepatu Adorable. Jurnal Universitas Indonesia.

Priyono, M. (2016). Metode Penelitian Kuantitatif. Sidoarjo: Zifatma Publishing.

Rina, A. W., Ronald, \& Amelia. (2014). Analisis faktor-faktor yang mempengaruhi Purchase Intention melalui Social Media terhadap Produk 